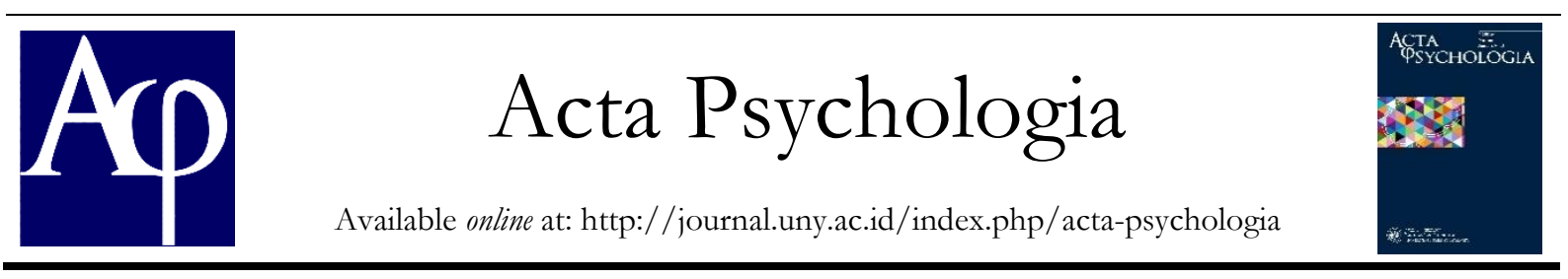

\title{
Hubungan antara Kecanduan Game Online dengan Pembelian Impulsif Perangkat Game pada Mahasiswa
}

\author{
Fausy Husni Mubarok \\ Jurusan Psikologi, Fakultas Ilmu Pendidikan, Universitas Negeri Yogyakarta; \\ Jl. Colombo No. 1 Sleman Yogyakarta, 55281 \\ fauzyhusnimubarok@gmail.com
}

\begin{abstract}
Abstrak
Tujuan penelitian ini adalah untuk mengetahui hubungan antara kecanduan game online dengan pembelian impulsif perangkat game. Penelitian ini merupakan penelitian kuantitatif dengan jenis korelasional. Populasi penelitian ini adalah mahasiswa usia dewasa awal yang berdomisili di Provinsi Daerah Istimewa Yogyakarta. Ukuran sampel sebanyak 100 orang yang ditentukan dengan purposive sampling dengan kriteria mahasiswa S1 berusia 18-24 tahun. Data dikumpulkan dengan menggunakan angket secara online melalui Google Form. Analisis data dilakukan dengan analisis deskriptif dan uji korelasional Pearson Product Moment menggunakan bantuan software SPSS. Hasil penelitian menunjukkan terdapat hubungan positif yang signifikan antara kecanduan game online dengan pembelian impulsif perangkat game $\left(\mathrm{r}=0.365, \mathrm{p}<0.05, \mathrm{R}^{2}=0.133\right)$. Dengan demikian semakin tinggi kecanduan game online maka semakin tinggi pembelian impulsif perangkat game. Kontribusi hubungan yang diberikan variabel kecanduan game online dengan pembelian impulsif perangkat game adalah sebesar $13.322 \%$.
\end{abstract}

Kata Kunci: kecanduan game, game online, pembelian impulsif, perangkat game

\begin{abstract}
The purpose of this study was to determine the relationship between online game addiction and impulsive purchasing of gaming devices. This research is a correlational study. The population of this research is students of early adulthood who live in the Province of Yogyakarta Special Region. The sample size was 100 people who were determined by purposive sampling with the criteria for undergraduate students aged 18-24 years. Data was collected using an online questionnaire via Google Form. Data analysis was performed using descriptive analysis and correlation test of Pearson Product Moment using SPSS software. The results showed that there was a significant positive relationship between the of online game addiction and the impulsive purchase of game devices $(\mathrm{r}=0.365, \mathrm{p}$ $<0.05, \mathrm{R} 2=0.133)$. Thus, the higher the of online game addiction, the higher the impulsive purchase of gaming devices. The relationship contribution given by the online game addiction variable with the impulsive purchase of game devices was $13.322 \%$
\end{abstract}

Keywords: game addiction, online games, impulsive buying, game devices

\section{Pendahuluan}

Game online atau permainan daring adalah permainan yang memanfaatkan jaringan koneksi internet untuk memainkannya. Bermain game online saat ini diketahui menjadi jenis kecanduan perilaku yang paling banyak terjadi terutama di Indonesia karena statistik mengatakan jumlah gamer (pemain game) di Indonesia saat ini diprediksi sudah mencapai 34 juta orang. Dari jumlah tersebut, 19,9 juta diantaranya adalah gamer online berbayar dan rata-rata pengeluarannya mencapai 9,12 dolar atau sekitar 130.000 rupiah. 
Perkembangan game online didukung dengan jumlah pengguna internet dunia yang semakin banyak. Berdasarkan WeareSocial survei yang dilaporkan DataReportal, pada awal tahun 2020, jumlah pengguna internet di dunia mencapai 4,5 miliar orang. Dari total pengguna internet dunia, sekitar $80 \%$ dari pengguna internet dalam rentang usia 16-64 tahun bermain game setiap bulannya sehingga total individu yang bermain game sebanyak 3,5 miliar orang.

Perkembangan teknologi memacu semakin mudahnya akses game online sehingga bisa dimainkan melalui smartphone yang pada awalnya hanya bisa dimainkan di komputer. Penyebab lainnya adalah semakin terjangkaunya harga smartphone serta harga smartphone yang relatif lebih terjangkau dibandingkan komputer dan konsol video game.

Game online sangat marak di kalangan mahasiswa di Yogyakarta. Penelitian terdahulu yang dilakukan Tattakuna (2016) tentang respon atas keberadaan game online di Yogyakarta ditemukan bahwa mayoritas pemain game online berstatus mahasiswa dewasa awal yang berusia 19-25 tahun. Rata-rata subjek dalam penelitian tersebut menghabiskan waktu dalam bermain game online yaitu hampir tiap hari bermain dan perharinya 5 sampai 15 jam.

Respon yang didapat atas keberadaan game online di kalangan mahasiswa Yogyakarta merupakan suatu fenomena yang mampu mengalahkan situssitus populer bertema jaringan sosial. Mahasiswa juga merupakan pelajar yang paling peka terhadap perkembangan teknologi sehingga keberadaan game online sudah menggejala. Mereka bermain game online dengan alasan pemenuhan kebutuhan atas apa yang mereka tidak dapatkan di dunia nyata, yaitu sebuah hasrat kesenangan status sosial, ekonomi dan kelompok interaksi. Hal-hal tersebut disimulasikan dalam game online sehingga mereka mau bermain dan tetap bermain game online.

Game online di kalangan mahasiswa memberikan dampak positif maupun negatif. Dampak positif tersebut seperti meningkatkan konsentrasi dan meningkatkan kemampuan berbahasa inggris. Sedangkan dampak negatifnya menjadi konsumtif dan menimbulkan efek ketagihan atau kecanduan perilaku (Tattakuna, 2016).

Mahasiswa adalah salah satu kelompok yang paling peka terhadap perkembangan teknologi salah satunya perkembangan teknologi yang dekat dengan mahasiswa adalah semakin maraknya game online. Mahasiswa yang terpapar dengan keberadaan game online akan mungkin bermain game online dan melakukan perilaku kecanduan game online).

Berdasarkan penelitian Young (2009) yang membahas akibat kecanduan game online pada individu dan keluarga mengatakan bahwa kecanduan game online adalah salah satu bentuk kecanduan yang mirip seperti kecanduan alkohol dan obatobatan. Tanda-tandanya sangat sulit dideteksi, peringatan sedini mungkin dengan melihat perilaku kecanduan game online penting untuk dilakukan mengingat industri game yang menargetkan banyak kaum muda, khususnya yang berusia dewasa awal. 
Seseorang yang mengalami kecanduan perilaku akan berdampak besar terhadap sisi kognitif, psikologis dan perilaku seseorang. Seseorang yang mengalami kecanduan perilaku yaitu kecanduan game online dapat menimbulkan dua konsekuensi adiksi, yakni fisik dan nonfisik (psikologis). Dilansir dari Tempo.co, menurut keterangan Kristiana Siste (Dokter Departemen Psikiatri FK UI RSCM) konsekuensi fisik dari seseorang yang terusmenerus memainkan game online tanpa kenal waktu hingga berjam-jam lamanya, antara lain dapat mengalami obesitas, cedera akibat terlalu lama menggunakan perangkat bermain game seperti carpal tunnel syndrome, gangguan tidur berakibat kurangnya konsentrasi, serta pola makan yang berantakan.

Sementara itu, konsekuensi nonfisik lebih mengarah pada emosional seseorang. Misalnya pada mahasiswa dampak non-fisik yang dapat timbul adalah memburuknya relasi dengan orang-orang sekitar, menurunnya tingkat kesantunan, hingga etos belajar yang rendah. Seorang pemain game online yang kecanduan akan memikirkan game saat offline dan sering berfantasi bermain game ketika mereka harus berkonsentrasi pada hal-hal lain. Alih-alih memikirkan tugas yang harus diselesaikan untuk kuliah atau sekolah, pergi ke kelas, atau belajar di perpustakaan, gamer jika seorang mahasiswa maka akan menjadi sepenuhnya fokusnya teralihkan pada bermain game. Gamer mulai kehilangan tenggat waktu, mengabaikan pekerjaan atau aktivitas sosial saat online dan bermain game menjadi prioritas utama mereka (Young, 2009).
Kecanduan atau adiksi adalah sesuatu yang berbahaya karena dapat menyebabkan pemain game online mendapatkan permasalahan yang lain. Banyak individu yang kecanduan game online ini melakukan banyak perilaku yang berkaitan dengan impulsivitas. Impulsivitas didefinisikan sebagai respon tergesa-gesa terhadap rangsangan, tindakan cepat, dan perilaku tanpa berpikiran memadai sering mengarah pada hasil yang tidak diinginkan utamanya di masa depan.

Bentuk salah satu perilaku impulsivitas yang menonjol di kalangan individu yang bermain game online adalah pembelian impulsif terhadap perangkat game. Pembelian impulsif perangkat game adalah pembelian impulsif adalah suatu perilaku pembelian perangkat game yang tergesa-gesa dilakukan secara spontan dan tidak terencana karena mengalami konflik perasaan untuk melakukan pembelian perangkat game sesegera mungkin tanpa berpikir dengan memikirkan konsekuensi dan pertimbangan-pertimbangan kognitif yang penting mengenai perangkat game yang dibeli.

Berdasarkan penelitian tentang impulsive buying pada pemain game online di Bandung, perbandingan elemen kognitif dengan elemen emosi pada gamers online Dragon Nest di warnet Digi Games kota Bandung didapat bahwa sebanyak $72 \%$ dari subjeknya melakukan pembelian impulsif terhadap barang di online shop maupun game online. Mayoritas responden diketahui memiliki perilaku kecanduan game online dengan memiliki elemen kognitif dalam kategori rendah dan elemen emosi dalam kategori tinggi dalam pembelian 
impulsif, yang dapat dikatakan bahwa dalam melakukan pembelian suatu barang, mereka masih didominasi oleh perasaannya (Gumeular \& Eryani, 2016).

Penelitian ini dilakukan berdasarkan survei awal melalui studi kasus yang dilakukan di Yogyakarta pada 26 Desember 2018 hingga Mei 2019 dengan subjek berjenis kelamin laki-laki yang berusia dewasa awal yaitu 21 tahun adalah salah satu teman peneliti yang bekerja di salah satu warnet atau internet learning café di Kabupaten Sleman, Daerah Istimewa Yogyakarta. Subjek termasuk seseorang yang mengalami kecanduan game sehingga mengeluarkan sebagian besar gajinya untuk membeli banyak perangkat game.

Karakteristik subjek dalam studi kasus tersebut adalah subjek memiliki hobi utama yaitu bermain game yang didapat sejak kecil ketika mulai diperkenalkan dengan salah satu perangkat game oleh orang tuanya pada masa balita. Subjek mengembangkan hobi bermain game dengan menelusuri berbagai macam jenis perangkat game dan orang tuanya cenderung permisif dan membebaskan subjek untuk bermain game. Pada saat masa sekolah subjek sering mengalami kecemburuan dan peer pressure karena tidak mampu membeli perangkat game yang dimiliki temannya lalu mulai mengumpulkan uangnya untuk membeli perangkat game sendiri. Orang tuanya pun membebaskan anaknya untuk membeli perangkat game dengan syarat memakai uang sendiri.

Setelah itu, pada saat subjek bekerja maka setiap gaji yang diperoleh sering bahkan hampir selalu gajinya dipakai untuk membeli perangkat game seperti joystick,
VGA, RAM, bahkan PS3 dalam satu kali penerimaan gaji. Bahkan selain perangkat game, subjek yang diteliti dalam studi kasus tersebut juga membeli aksesoris, mainan, action figure, hingga LEGO yang berhubungan dengan karakter atau game yang dimainkan olehnya. Namun, dilandasi oleh keterangan bahwa subjek mengkategorikan dirinya dan keluarganya sebagai golongan ekonomi menengan ke bawah, selang beberapa hari setelah pembelian perangkat game, subjek sering mengeluh karena telah menghabiskan sebagian besar uangnya untuk membeli perangkat game padahal masih terdapat kebutuhan pokok hingga kebutuhan mendesak lainnya sehingga terpaksa sering meminjam uang kepada temannya.

Dilakukan uji tes Rorscharch pada subjek tersebut dan hasilnya subjek sering mengaitkan bercak tinta Rorscharch dengan karakter dalam game yang subjek mainkan. Dilakukan asesmen Edward Compulsive Buying Test pada subjek dan hasilnya subjek memiliki jumlah skor 43 yang masuk dalam kategori borderline dengan derajat keparahan 3 dari 5 tingkatan derajat keparahan. Melalui alloanamnesa, dilaporkan oleh teman subjek yang juga bekerja di warnet bersama subjek tersebut bahwa subjek adalah tipe ekstravert yang memiliki impulsivitas tinggi ditandai sering murung bahkan marahmarah ketika mulai atau saat awal waktu bekerja akibat waktu bermain gamenya berhenti karena jadwal bekerja. Observasi yang dilakukan ke rumah subjek, subjek memperlihatkan di dalam rumah dan kamarnya terdapat banyak perangkat game yang masih berfungsi seperti Personal Computer, Nintendo, Play Station dan banyak koleksi perangkat game yang sudah rusak 
yang belum sempat dijual lagi oleh subjek. Kamar subjek dipenuhi mainan-mainan, aksesoris, CD game, dan action figure yang berhubungan dengan karakter game yang pernah dimainkannya.

Permasalahan dalam studi kasus tersebut relevan dengan penelitian ini dimana seseorang dengan kecanduan game akan rentan melakukan perilaku pembelian impulsif perangkat game. Pembelian impulsif perangkat game adalah salah satu perilaku impulsivitas dimana seseorang melakukan perilaku tanpa berpikir dan rentan untuk merasa menyesal dan mendapatkan konsekuensi negatif di masa depan seperti permasalahan ekonomi karena uang yang habis padahal masih terdapat kebutuhan yang lebih mendesak daripada membeli perangkat game.

Sebelum penulisan penelitian ini dilakukan dan sebelum masa pandemi COVID-19, untuk memastikan bahwa game online memang masih marak di Yogyakarta, peneliti melakukan kunjungan observasi ke beberapa warnet-warnet di Yogyakarta untuk memastikan bahwa masih banyak mahasiswa yang masih memiliki hobi bermain game online hingga mengalami kecanduan game online. Tempat-tempat bermain game online yang terkenal di Yogyakarta seperti Gamer Village Yogyakarta, Nafero Gamenet, Platinum Gamenet, dan Z Net mayoritas dikunjungi oleh gamers yang mempunyai latar belakang mahasiswa. Hal ini berarti terdapat perilaku kecanduan game online bagi mahasiswa sehingga selanjutnya mengarah pada perilaku kecanduan game online tinggi karena game online marak di kalangan mahasiswa berusia dewasa awal. Selain itu, bermain game online dapat berkaitan dengan perilaku impulsif terhadap perangkat game. Individu yang melakukan pembelian impulsif rentan untuk merasa menyesal karena telah melakukan pembelian impulsif karena pengeluaran mereka menyebabkan permasalahan ekonomi serta permasalahan lain di masa depan.

Penelitian ini dilakukan sebagai suatu peringatan sedini mungkin dengan melihat perilaku kecanduan game online yang mengarah kepada kecanduan game online tingkat tinggi penting untuk dilakukan mengingat industri game yang menargetkan banyak kaum muda, khususnya bagi mahasiswa yang berusia dewasa awal yang sedang menempuh pendidikan.

Penelitian ini sangat penting dilakukan karena penelitian ini terdapat kebaruan. Penelitian mengenai kecanduan game online dan pembelian impulsif di Indonesia masih sangat sedikit dan penelitian yang meneliti kecanduan game online atau pembelian impulsif jika dihubungkan dengan variabel lain masih berkutat dengan variabel seperti kontrol diri, motivasi belajar dan prokrastinasi akademik. Penelitian terdahulu yang meggabungkan antara kecanduan game online dengan pembelian impulsif ditemukan hanya meneliti sebatas statistik deskriptif, sejauh ini belum ada penelitian yang melakukan penelitian dengan statistik inferensial guna menguji bagaimana hubungan antara kecanduan game online dengan perilaku pembelian impulsif terhadap perangkat game. 


\section{Metode Penelitian}

Jenis penelitian

Jenis penelitian yang dilakukan peneliti adalah jenis penelitian korelasional. Penelitian korelasional adalah jenis penelitian yang melibatkan kegiatan pengumpulan data untuk menentukan hubungan antara dua variabel atau lebih.

\section{Waktu dan tempat penelitian}

Penelitian ini dilakukan di Provinsi Daerah Istimewa Yogyakarta dan berlangsung pada rentang waktu 14 Juni-31 Agustus 2020.

\section{Subjek Penelitian}

Teknik sampling menggunakan nonprobability sampling yaitu bentuk purposive sampling dengan kriteria atau pertimbangan tertentu (Jogiyanto, 2005). Kriteria subjek yaitu: (1) mahasiswa usia 18-40 tahun di Yogyakarta, (2) sering bermain game online, dan (3) pernah melakukan pembelian perangkat game setidaknya tiga kali transaksi untuk keperluan bermain game online. Perangkat game yang dimaksud adalah perangkat untuk bermain game online seperti headphone, kursi gaming, kuota internet game, biaya sewa internet cafe, membeli konsol atau handphone untuk bermain game atau item dalam game online dan lain-lain. Kemerinstekdikti (2018) mengemukakan bahwa mahasiswa S1 rata-rata berada dalam rentang usia 18-24 tahun. Subjek akhir yang dilibatkan yaitu berjumlah 100 mahasiswa.

\section{Teknik pengumpulan data dan instrumen}

Teknik pengumpulan data pada penelitian ini menggunakan skala. Skala adalah sejumlah pertanyaan tertulis yang jawabannya diisi oleh subjek (Kumar, 1996). Skala pengukuran yang digunakan yaitu skala respon yang menyerupai model Likert. Skala yang digunakan yaitu skala kecanduan game online dan skala pembelian impulsive perangkat game. Aitem-aitem dalam skala kecanduan game online dan skala pembelian impulsif perangkat game mengungkap tingkat kecanduan dan tingkat pembelian impulsif perangkat game yang dilakukan subjek. Skor yang diberikan bergerak dari 1=Tidak Pernah, 2=Jarang, 3=Sering, hingga $4=$ Selalu.

Skala kecanduan game online yang digunakan merupakan modifikasi Game Addiction Questionnaire dari Lemmens et al. (2009) dan Indonesian Online Game Addiction Questionnaire dari Jap et al., (2013). Skala tersebut berisi ciri-ciri perilaku dari orang yang kecanduan game online dari DSM V.

Skala pembelian impulsif perangkat game dimodifikasi peneliti dari The Impulsive Buying Tendency Scale (Verplanken \& Herabadi, 2001). Skala yang dikembangkan didasari dua aspek pembelian impulsif yaitu aspek kognitif dan aspek afektif, dilakukan penambahan keterangan waktu yaitu sebelum atau saat pembelian perangkat game dan sesudah membeli perangkat game untuk mengetahui kecenderungan yang dialami pada subjek penelitian

\section{Teknik. Analisis data}

Analisis data dilakukan dengan analisis deskriptif dan uji korelasi menggunakan pearson Product Moment dengan bantuan software SPSS.

\section{Analisis Deskriptif}

Analisis deskriptif dilakukan untuk menggambarkan tanggapan responden mengenai tingkatan kategori kecanduan game online dan pembelian impulsive perangkat game. Data hasil penelitian dikategorisasikan menjadi tiga kelompok tingkatan yaitu tinggi, sedang, dan rendah. Pengkategorisasian data dilakukan berdasarkan nilai rata-rata (Mean) dan standard deviation (SD) masing-masing variabel penelitian berdasar data empiris (lapangan). 


\section{Uji Korelasi}

Uji korelasional dilakukan untuk menguji hubungan antara kecanduan game online (X) dengan pembelian impulsif perangkat game (Y). Uji korelasi yang digunakan yaitu korelasi Product Moment dari Pearson. Pengujian dilakukan dengan bantuan software SPSS hingga kemudian diperoleh koefisien korelasi antara variabel $\mathrm{X}$ dan $\mathrm{Y}$. Signifikansi hubungan antara kecanduan game online dengan pembelian impulsif perangkat game dilihat dari nilai $\mathrm{p}$ untuk mengetahui apakah hubungan yang telah ditemukan berlaku untuk seluruh populasi atau tidak. Kriteria penolakan Ho dan penerimaan $\mathrm{Ha}$ dilakukan berdasarkan nilai signifikansi, yaitu jika signifikansi $(\mathrm{p})<0,05$ disimpulkan bahwa hubungan antara kedua variabel penelitian signifikan. Setelah melihat nilai korelasi (r) dan signifikasi (p), peneliti menghitung nilai $\mathrm{R}^{2} \cdot \mathrm{R}^{2}$ didapat dengan mengkuadratkan koefisien korelasi (r) yang menunjukkan seberapa besar kontribusi hubungan yang diberikan variabel kecanduan game online $(\mathrm{X})$ dengan pembelian impulsif perangkat game $(\mathrm{Y})$.

\section{Hasil Penelitian dan Pembahasan}

\section{Hasil Uji Deskriptif}

Berdasarkan hasil uji deskripitif pada variabel kecanduan game online, sebanyak 10 subjek (10\%) memiliki skor kecanduan game online $>27$ atau tinggi; sebanyak 75 orang (75\%) memiliki skor di rentang 17-27 atau sedang, dan 15 orang (15\%) memiliki skor di bawah 17 atau rendah. Variabel kecanduan dijelaskan lagi berdasarkan aspek salience, relapse, masalah, penarikan, konflik, tolerance, dan modifikasi suasana hati. Responden memberi tanggapan dengan skor terbanyak pada aspek modifikasi suasana hati dengan jumlah skor sebanyak 270 (18\%). Skor terendah yaitu pada aspek konflik dengna skor $147(10 \%)$.

Untuk variabel pembelian impulsive perangkat game, sebanyak 13 orang $(13 \%)$ memiliki skor pembelian impulsive perangkat game $>22$ atau berada di kategori tinggi; 67 orang $(67 \%)$ memiliki skor antara 11-22 atau kategori sedang; dan 20 orang (20\%) memliliki skor di bawah 11 atau berada di kategori rendah. Variabel pembelian impulsive perangkat game dijelaskan lebih lanjut berdasarkan aspek kognitif sebelum atau saat pembelian perangkat game, kognitif sesudah pembelian perangkat game, afektif sebelum atau saat pembelian perangkat game, dan afektif setelah pembelian perangkat game. Berdasarkan aspeknya, responden memberi respon dengna skor terbanyak pada aspek afektif dengan waktu sesudah pembelian perangkat game dengan skor terbanyak 174 $(26,05 \%)$. Sedangkan tanggapan responden dengan skor terendah yaitu pada aspek kognitif dengna waktu sebelum pembelian perangkat game dengan skor 153 (22,9\%).

\section{Hasil Uji Korelasi}

Uji korelasi dilakukan pada skor total kecanduan game online $(\mathrm{X})$ dan skor total pembelian impulsive perangkat game $(\mathrm{Y})$. hasil analisis dapat dilihat pada Tabel 1.

Tabel 1. Hasil uji korelasi product moment

\begin{tabular}{lll}
\hline & & $\mathrm{Y}$ \\
\hline $\mathrm{X}$ & Pearson Correlation & $.365^{* *}$ \\
Sig. (2-tailed) & .000 \\
$\mathrm{~N}$ & 100 \\
\hline
\end{tabular}

Berdasarkan Tabel 1, diperoleh angka pearson correlation $(r)$ antara kecanduan game online dan pembelian impulsive perangkat game sebesar 0.365 dengan signifikansi sebesar $0.000(\mathrm{p}<0.05)$. berdasarkan nilai $\mathrm{r}$ sebesar 0,365 kemudian didapat nilai $\mathrm{R}^{2}$ atau koefisien determinasi sebesar $13.322 \%$

\section{Pembahasan}

Berdasarkan uji korelasi dengan Product moment dari Pearson ditemukan bahwa terdapat hubungan positif yang signifikan antara kecanduan game online dan pembelian impulsive perangkat game. Dengan demikian semakin tinggi kecanduan game online maka 
semakin tingi pula perilaku pembelian impulsive perangkat game. Sumbangan efektif yang diberikan $\left(\mathrm{R}^{2}\right)$ variabel kecanduan game online terhadap perilaku pembelian impulsive perangkat game yaitu sebesar $13.322 \%$, sisanya sebesar $86.678 \%$ dipengaruhi oleh variabel lain. Hasil penelitian ini sejalan dengan hasil penelitian Gumeular dan Eryani (2016) yang menemukan bahwa pemain game online cenderung melakukan impulsive buying terhadap barang baik di online shop maupun di game online. Dilaporkan sebanyak $72 \%$ responden penelitian tersebut melakukan pembelian impulsif dan masuk ke kategori impulsive buying tinggi.

Hasil analisis deskriptif mengenai kecanduan game online menunjukkan sebagian besar responden masuk kecanduan game online pada tingkat kategori sedang, yaitu sebanyak 75 orang $(75 \%)$ dan sebagian kecil masuk ke dalam kecanduan game online pada tingkat kategori tinggi, yaitu sebanyak 10 orang $(10 \%)$. Hal ini cukup mengkhawatirkan karena sebagian besar responden yang merupakan mahasiswa berusia dewasa awal sudah mencapai tingkat kategori sedang kecanduan game online yang dapat masuk ke tingkat kategori tinggi. Semakin tinggi tingkat kategori kecanduan game online yang dialami maka semakin dekat dengan keadaan kecanduan game online. Selain itu semakin tinggi kemungkinan mengalami akibat dari berbagai resiko bermain game online yang berlebihan.

Hasil penelitian ini juga selaras dengan hasil penelitian Griffiths (dalam Rochmah, 2011) yang menunjukan bahwa tidak hanya remaja saja yang bisa mengalami kecanduan game online, tetapi orang dewasa juga memiliki kemungkinan untuk mengalaminya. Penelitian ini menunjukkan bahwa mahasiswa yang berusia dewasa awal dapat mengalami kecanduan game online karena telah melakukan kecanduan game online pada tingkat kategori tinggi dan sedang. Hal ini disebabkan oleh beberapa faktor motivasi yang menjadi kecanduan game online, yaitu relationship, manipulation, immersion, escapism, dan achievement (Yee, 2005).

Faktor relationship merujuk pada keinginan untuk berinteraksi dengan orang lain dalam dunia virtual game online sehingga membentuk kelompok interaksi. Pada saat penelitian ini berlangsung, mahasiswa yang menjadi responden penelitian banyak berdiam diri di rumah karena kebijakan pembatasan sosial dari pemerintah terkait pandemi COVID-19 sehingga banyak dari mereka merasa kesepian sehingga game online menjadi salah satu alternatif untuk berinteraksi dengan orang lain. Faktor selanjutnya yang didukung dampak dari pandemi COVID-19 kepada banyak orang adalah faktor escapism. Sebagai akibat dari stress karena pandemi dan dirumahkan, responden penelitian membutuhkan sarana untuk menghindari, melupakan, dan pergi dari stress yang dialami di dunia nyata sehingga bermain game online adalah solusinya. Diperkuat dengan data hasil penelitian pada aspek modifikasi suasana hati menjadi aspek dengan skor terbanyak pada tanggapan responden secara keseluruhan (18\%).

Faktor selanjutnya yang mempengaruhi kecanduan game online adalah faktor manipulation, immersion dan achivement. Faktor manipulation merujuk pada bahwa game online menjadi salah satu penyaluran untuk menjadikan pemain lain sebagai objek untuk kepuasan diri dengan memanipulasi orang lain. Faktor immersion adalah ketika seseorang lebih menyukai menjadi orang lain dalam dunia virtual yaitu game online. Terakhir, faktor achievement yaitu seseorang bermain game online dilandasi oleh keinginan untuk menjadi lebih kuat setiap harinya dalam dunia game online melalui pencapaian dalam game tersebut dan akumulasi item-item dalam game online yang biasanya bisa dibeli dengan uang (pay to win) yang dapat memicu resiko perilaku pembelian impulsif perangkat game. 
Salah satu faktor yang berperan dalam munculnya pembelian impulsif dalam penelitian ini dapat dijabarkan berdasarkan teori konstruksi sosial pembelian impulsif (Dittmar et al., 1995). Motivasi internal dari pembelian impulsif dapat terjadi karena sebagai sarana "pelarian" untuk mencari suasana hati dan mood positif (Dittmar et al., 1996). Faktor tersebut yakni kebutuhan untuk membeli barang sebagai simbol materi identitas pribadi dan sosial untuk ditunjukkan kepada orang lain. Didukung hasil penelitian dengan banyaknya responden yang bermain game online sebagai sarana "pelarian" dari masalah dunia nyata dalam aspek modifikasi suasana hati. Hal tersebut untuk mendapatkan mood positif sehingga responden yang bermain game online rentan melakukan pembelian impulsif terhadap barang yang mereka mau untuk menunjukkan identitas dirinya atau untuk membuat dirinya senang, seperti membeli peralatan untuk bermain game atau barang virtual yang dibutuhkan untuk bermain game online mereka di toko-toko online atau gameshop game yang mereka mainkan.

Diperkuat dengan faktor yang mempengaruhi pembelian impulsif yaitu faktor produk dengan karakteristik harga yang murah dan letak toko yang mudah dijangkau (Louden dan Bitta, 1993). Salah satu hal yang menjadi efek dari pandemi COVID-19 yang menambah rangsangan kepada responden adalah bangkitnya bisnis toko online yang semakin memudahkan orang-orang untuk melakukan pembelian impulsif karena letak toko yang semakin mudah dijangkau, bahkan bisa membeli hanya dengan menggunakan handphone sembari berdiam diri di rumah. Iklan-iklan toko online di media secara terus-menerus dan sugestibel yang sangat agresif dilakukan oleh toko online sebagai strategi pemasaran pun turut menjadi salah satu faktor yang berperan dalam memicu pembelian impulsif perangkat game di kalangan mahasiswa.

Diperlukan peringatan sedini mungkin dengan melihat perilaku kecanduan game online yang mengarah kepada kecanduan game online serta berkaitan signifikan dengan pembelian impulsif perangkat game, penting bagi mahasiswa berusia dewasa awal meningkatkan control beliefs yang dapat menahan perilaku bermain game online dan pembelian impulsif perangkat game. Kontrol diri diperlukan untuk memperkuat upaya pencegahan perilaku kecanduan game online dan pembelian impulsif perangkat game, mengingat maraknya game online dan industri game yang menargetkan banyak kaum muda, khususnya bagi mahasiswa yang berusia dewasa awal yang sedang menempuh pendidikan. Efek dan dampak negatif yang beresiko merugikan di masa depan rentan terjadi jika mengalami kecanduan game online dan melakukan pembelian impulsif perangkat game.

\section{Simpulan dan Saran}

Simpulan

Terdapat hubungan positif yang signifikan antara kecanduan game online dengan pembelian impulsif perangkat game pada mahasiswa berusia dewasa awal di Yogyakarta. Kontribusi hubungan yang diberikan variabel kecanduan game online terhadap perilaku pembelian impulsif perangkat game adalah sebesar 13,322\%.

Saran

Berdasarkan kesimpulan dari penelitian yang sudah dilakukan, maka saran yang dapat diberikan sebagai berikut :

\section{Untuk Penelitian Selanjutnya}

Hasil penelitian terkait hubungan kecanduan game online dengan pembelian impulsif perangkat game bisa difollow up dengan melihat hubungannya dengan variabel lain yang belum dikaji pada penelitian ini. Salah satu topik yang dapat dijadikan pertimbangan yaitu melihat hubungan dan pengaruh tas jam bermain seseorang yang melakukan kecanduan game 
online dengan pembelian impulsif perangkat game.

\section{Untuk Mahasiswa usia Dewasa Awal}

Diharapkan penelitian ini memberikan pengetahuan sebagai tanda siaga untuk mahasiswa agar dapat menerapkan kontrol terhadap perilaku bermain game online dan pembelian perangkat game. Mengingat mahasiswa termasuk kelompok yang peka terhadap perkembangan teknologi, rentan terpapar perkembangan teknologi game online yang semakin marak dan industri game yang menargetkan banyak kaum muda khususnya yang berusia dewasa awal.

Mahasiswa usia dewasa awal perlu mengetahui tanda-tanda perilaku yang mengarah pada kecanduan game online. Jika memang ingin bermain game online untuk hiburan maka dapat dilakukan sewajarnya. Diharapkan mahasiswa mulai belajar mengontrol diri untuk berhenti jika sudah mencapai perilaku kecanduan. Jika mengalami kesulitan untuk mengendalikan perilaku bermain game online dapat meminta bantuan kepada orang lain khususnya bantuan orang terdekat dan profesional yang berwenang di bidang psikologi.

Untuk mengendalikan pembelian impulsif perangkat game agar tidak sampai pada taraf mengganggu dan merugikan keadaan ekonomi di kemudian hari maka tetap lakukan dan membiasakan pertimbangan kognitif yang penting ketika membeli perangkat game. Kenali konflik perasaan yang muncul saat membeli perangkat game ditambah melakukan pertimbangan dari sisi kognitif terbukti dapat menekan aspek afektif untuk membeli perangkat game sesegera mungkin. Memikirkan konsekuensi negatif di masa depan yang merugikan ketika membeli barang juga akan menambah kontrol diri agar tidak melakukan pembelian impulsif perangkat game.

\section{Daftar Pustaka}

Adams, E. \& Rolling, A. (2010). Fundamentals of game design. (2nd ed.). Barkeley, CA : New Riders.

Ajzen, I. \& Fishbein, M. (1980). Understanding attitudes and predicting social behavior. Englewood Cliffs, NJ: Prentice-Hall.

Amalia, E.I. (2020). Jumlah gamer di dunia capai 3,5 miliar orang diakses tanggal 22 Juni 2020 dari https://hybrid.co.id/post/jumlahgamer-di-dunia-capai-35-miliar-orang.

American Psychiatric Association. (2013). Diagnostic and statistical manual of mental disorder edition (DSM-V). Washington: American Psychiatric.

Arikunto, S. (2002). Metodologi penelitian suatu pendekatan proposal. Jakarta: PT. Rineka Cipta.

Arikunto, S. (2010). Prosedur penelitian suatu pendekatan praktik. Jakarta: PT Rineka Cipta.

Azwar. S. (2012). Metode penelitian. Yogyakarta: Pustaka Pelajar.

Chaplin, J.P. (2004). Kamus lengkap Psikologi. Jakarta: PT Raja Grafindo Persada.

Creswell, J.W. (2014). Research design pendekatan kualitatif, kuantitatif, dan mixed. Yogyakarta: Pustaka Pelajar.

Dittmar, H. \& Drury, J. (2000). Self-image is it in the bag? A qualitative comparison between "ordinary" and "excessive" consumers. Journal of Economic Psychology, 21(2), 109-142.

Dittmar, H., Beattie, J., Friese, S. (1996). Objects, decision considerations and self-image in men's and women's 
impulse purchases. Acta Psychologica, 93, 187-206.

Dittmar, H., Beatty, J., Friese, S. (1995). Gender identity and material symbols: Objects and decision considerations in impulse purchases. Journal of Economic Psychology, 16, 3, 491-511.

Drajat, E.K. (2017). Pengaruh tas bermain game online terhadap perilaku prokrastinasi akademik pada Mahasiswa Bimbingan Konseling Universitas PGRI Yogyakarta. Jurnal Konseling GUSJIGANG, 3(1).

Fauzi. (2019). Pengaruh game online PUBG (Player Unknown's Battleground) terhadap prestasi belajar peserta didik. ScienceEdu, 2, 1, 61-66.

Gumeular, A.T. \& Eryani, R.D. (2016). Studi deskriptif mengenai impulsive buying pada Gamers Game Online Dragon Nest Kota Bandung. Prosiding Psikologi Fakultas Psikologi Universitas Islam Bandung tahun akademik 20152016 Gelombang 2. Bandung: Universitas Islam Bandung.

Hetharie, J.A. (2011). Peran emosi positif sebagai mediator stimulus lingkungan toko dan faktor sosial terhadap impulse buying tendency pada Matahari Departement Store Kota Ambon. Jurnal Aplikasi Manajemen, 10(4), 890898.

Hurlock, E. (1996). Psikologi perkembangan. Alih bahasa: dr. Med. Metasari T. \& Dra. Muslichah Z. Jakarta: Erlangga.

Ilmana. (2012). Analisis motivasi konsumen online dalam melakukan impulsive buying pada transaksi C2C Commerce. Jakarta: Universitas Indonesia.

Jap, T., Tiatri, S., Jaya, E.S., et al. (2013). The development of Indonesian Game
Addiction Questionnaire. PLOS ONE, 8(4), 1-5.

Kollat, D. \& Willett, R. (1969). Is impulse purchasing really a useful concept for marketing decisions?. Journal of Marketing (pre-1986); Jan 1969; 33, 79-8.

Lemmens, J.S., Valkenburg, P.M., Peter. J. (2009). Development and validation of a Game Addiction Scale for Adolescents. Media Psychology, 12(1), 77 95.

Louden, D.L \& Bitta, A.J.D. (1993). Consumer behavior: Concept and applications. The United State of America: By McGraw Hill Inc.

Pratiwi, Y. (2018). Kecanduan game online dampaknya gangguan dari fisik sampai otak diakses tanggal 22 Juni 2020 https://cantik.tempo.co/read/110517 $3 /$ kecanduan-game-online-dampaknyagangguan-dari-fisik-sampai-otak.

Rachmawati, A.R. (2018). Gamer Indonesia diprediksi capai 34 juta orang. Diakses tanggal 22 Juni 2020 dari https://www.pikiranrakyat.com/ekonomi/pr01299954/gamer-indonesia-diprediksicapai-34-juta-orang-428379.

Rochmah, S. (2011). Pengaruh komunikasi interpersonal dan loneliness terhadap adiksi game online". (Skripsi, tidak diterbitkan). Jakarta: Psikologi, Fakultas Psikologi, Universitas Islam Negeri Syarif Hidayatullah Jakarta.

Samhadi, S. H. (2006). Dalam cengkeraman konsumtivisme. Jakarta: Kompas.

Santoso, Y.R.D. \& Purnomo, J.T. (2017). Hubungan kecanduan game online terhadap penyesuaian sosial pada remaja. Jurnal Humaniora Yayasan Bina Dharma, 1(1), 27-44. 
Sarafino, E.P. (1990). Health psychology. Singapore: John Wiley and Sons.

Stern, H. (1962). The significance of impulse buying today. Journal of Marketing, 26(2), 59-62.

Stern, Rook, D. (1987). The buying impulse. The Journal of Consumer Research, 14(2), 189-199.

Tattakuna, N. (2016). Game online dan mahasiswa (Studi tentang respon mahasiswa atas keberadaan game online). (Skripsi, tidak diterbitkan). Yogyakarta: Sosiologi, Fakultas Ilmu Sosial dan Politik Universitas Gadjah Mada Yogyakarta.

Tinarbuko, S. (2006). Pola bidup konsumtif masyarakat Yogya. Jakarta: Kompas.

Ulfa, M. (2017). Pengaruh kecanduan game online terhadap perilaku remaja di Mabes Game Center Jalan HR. Subrantas Kecamatan Tampan Pekanbaru. JOM. FISIP Jurusan Sosiologi, 4(1), 1-13.

Verplanken, B. \& Herabadi, A. (2001). Individual differences in impulse buying tendency: Feeling and no thinking. European Journal of Personality, 15, S71-S83.

Yee, N. (2006). Motivation for plays in online games. CyberPsychology \& Behavior, 9(6), 772-775.

Yee, N. (2006). The demographics, motivations and derived experiences of users of massively-multiuser online graphical environments. PRESENCE: Teleoperators and Virtual Environments, 15, 309-329.

Young, K. S. (2009). Understanding online gaming addiction and treatment issues for adolescents. The American Journal of Family Therapy. 37, 355-372. 